\title{
PENINGKATAN HASIL BELAJAR PESERTA DIDIK KELA IV TEMA 4 (BERBAGAI PEKERJAAN) MELALUI MODEL PEMBELAJARAN PROBLEM BASED LEARNING
}

\author{
Yuni Indriyani ${ }^{1}$, Pungkas Afi Arianto ${ }^{2}$ \\ ${ }^{1}$ PGSD FKIP Universitas Pasundan, ${ }^{2}$ SDN Kebokura \\ 1yuniindriyani@unpas.ac.id, 2ipunkavi98@gmail.com,
}

\begin{abstract}
The problem of this research is the low learning outcomes of students, especially in Theme 4. Students still do not meet the completeness of the KKM value. The purpose of this study is to improve student learning outcomes through the Problem Based Learning Model in Learning Theme 4 Class IV Semester 1 SDN 1 Kebokura. The subjects of this study were fourth grade students of SDN 1 Kebokura. This research is a Classroom Action Research which lasts for two cycles consisting of planning, action, observation and reflection stages. The data collection technique in this research is a student evaluation test which consists of knowing the learning outcomes of students. Based on the research results obtained in this study, it can be concluded that the learning outcomes of Theme 4 students of class IV SDN 1 Kebokura can be increased by using the Problem Based Learning model. The increase in learning outcomes can be seen from the initial condition of the average score of 64.5 with a percentage of the number of students who completed $41.6 \%$. In the first cycle there was an increase in the average value of 77.6 with the percentage of the number of students who completed $75 \%$, with a target of $85 \%$. Then in the second cycle there was an increase in the average score of 89.3 with the percentage of students who completed $100 \%$, with a target. Based on the results of the study, it can be concluded that there is an increase in student learning outcomes in Theme 4 using the Problem Based Learning model.
\end{abstract}

Keywords: Learning Outcomes, Problem Based Learning Model, PBL

\section{ABSTRAK}

Permasalahan penelitian ini adalah rendahnya hasil belajar siswa khususnya pada Tema 4. Peserta didik masih belum memenuhi ketuntasan nilai KKM Tujuan penelitian ini adalah Meningkatkan Hasil Belajar Peserta Didik Melalui Model Problem Based Learning Pada Pembelajaran Tema 4 Kelas IV Semester 1 SDN 1 Kebokura.Subjek penelitian ini adalah siswa kelas IV SDN 1 Kebokura. Penelitian ini merupakan Penelitian Tindakan Kelas yang berlangsung selama dua siklus yang terdiri dari tahap perencanaan, tindakan, observasi dan refleksi.Teknik pengumpulan data dalam penelitian ini adalah Tes soal evaluasi siswa yang terdiri untuk mengetahui hasil belajar peserta didik. Berdasarkan hasil penelitian yang 
diperoleh dalam penelitian ini maka dapat disimpulkan bahwa hasil belajar Tema 4 peserta didik kelas IV SDN 1 Kebokura dapat meningkat dengan menggunakan model Problem Based Learning. Peningkatan hasil belajar dapat dilihat dari kondisi awal nilai rata-rata sebesar 64,5 dengan presentase jumlah siswa yang tuntas $41,6 \%$. Pada siklus I terjadi peningkatan nilai rata-rata sebesar 77,6 dengan presentase jumlah siswayang tuntas adalah $75 \%$, dengan target sebesar $85 \%$. Kemudian pada siklus kedua terjadi peningkatan nilai rata- rata sebesar 89,3 dengan jumlah presentase siswa yang tuntas adalah $100 \%$, dengan target sebesar. Berdasarkan hasil penelitian dapat disimpulkan bahwa terdapat peningkatan hasil belajar Peserta didik pada Tema 4 menggunakan model Problem Based Learning.

Kata Kunci: Hasil Belajar, Model Problem based Learning, PBL.

\section{A. Pendahuluan}

Pada masa pandemi Covid 19, Pembelajaran di kelas tinggi sekolah dasar dilaksanakan secara Daring dan Luring. Pelaksanaan pembelajaran secara luring saat ini baru berjalan $50 \%$. Pelaksanaan pembelajaran luring dan daring sekaligus menjadi sarana bagi sekolah untuk mengembangkan keterampilan pembelajaran abad 21, diantaranya adalah penggunaan aplikasi berbasis internet dalam pembelajaran guna meningkatkan hasil belajar.

Belajar merupakan salah satu langkah untuk meningkatkan ilmu pengetahuan dan menambah wawasan bagi siswa. Belajar adalah ungkapan yang menunjukkan aktivitas (yang menghasilkan) perubahan-perubahan tingkah lakuatau pengalaman Faizah, (2017 hal, 10). Belajar akan lebih berhasil jika tujuan belajar berhubungan dengan aktivitas belajar itu sendiri atau berhubungan kebutuhan hidupnya Pane \& Dasopang, (2017, hlm, 12). Belajar lebih banyak berhubungan dengan aktivitas jiwa, dengan kata lain faktor-faktor psikis memang memiliki peran yang sangat menentukan di dalam belajar Setiawan ( 2017 hlm 15).

Hasil belajar adalah perubahanperubahan yang terjadi pada siswa, baik perubahan yang menyangkut aspek kognitif, afektif, dan psikomotorik sebagai hasil dari kegiatan pembelajaran yang telah dilakukan Susanto, (2013 hlm 5). Dalamtaksonomi Bloom hasil belajar lebih memusatkan perhatian terhadap pengetahuan, sikap, dan keterampilan Suyono, (2011 hlm 67). Sehingga dapat disimpulkan bahwa 
hasil belajar adalah kemampuankemampuan yang dimiliki oleh siswa setelah ia mengikuti kegiatan pembelajaran dan mendapat pengalaman dari kegiatan belajar yang telah dilaksanakan. Pada penelitian tindakan kelas ini peneliti memusatkan pada ranah kognitif saja, Faktor-faktor yang mempengaruhi hasil belajar diantaranya kecerdasan anak, kesiapan atau skematangan siswa dalam mengikuti kegiatan belajar, minat siswa dalam belajar, model penyajian materi pembelajaran yang disediakan oleh guru, dan suasana belajar yang menyenangkan sehingga membuat siswa menjadi lebih senang dalam pembelajaran (Susanto,2013 hlm, 15-18). Sedangkan menurut Sabri hasil belajar dipengaruhi oleh faktor dari dalam diri mereka dan faktor lingkungan. Faktor-faktor inilah yang menjadi pertimbangan dalam melakukan perbaikan model pembelajaran yanga ada (Sabri, 2007, hlm 45)

Pada kenyataannya sekarang, penerapan belajar yang efektif di sekolah masih sulit diterapkan dikarenakan banyak siswa yang masih kurang aktif dalam mengikuti pembelajaran. Salah satu Faktor penyebab rendahnya hasil belajar siswa dalam mengikuti pembelajaran pada peserta didik kelas IV SD Negeri 1 Kebokura tahun pelajaran 2021/2022 diantaranya dalam penyampaian materi pembelajaran yang selalu berpusat pada guru dimana guru hanya memfokuskan penyampaian informasi kepada siswa melalui ceramah, hal ini menimbulkan kurangnya kesempatan siswa untuk ikut aktif didalam pembelajaran karena siswa lebih banyak diam dan mendengarkan sehinga aktivitas belajar mengajar kurang efektif. Selain itu, siswa tidak dapat menangkap pelajaran dengan optimal dan masih banyak siswa yang bermain sedniri pada waktu pembelajaran. Faktor lain adalah kurangnya kesadaran dari diri siswa bahwa belajar adalah suatu kebutuhan. proses pembelajaran yang terjadi di belum menggunakan model pembelajaran yang mampu meningkatkan hasil belajar siswa.

Hasil pengamatan awal menunjukkan peserta didik kelas IV SD Negeri 1 Kebokura masih rendah hasil belajarnya. Nilai rata- rata ulangan harian yang belum mencapai 
KKM. Berbagai upaya peningkatan hasil belajar tersebut telah dilakukan, namun belum mencapai hasil yang maksimal karena belum menggunakan model pembelajaran yang sesuai dan belum memiliki potensi untuk meningkatkan kompetensi hasil belajar pada peserta didik.

Beberapa penyebab peserta didik mengalami kesulitan dalam proses memahami materi yang diajarkan oleh guru, bahan ajar yang terbatas, media pembelajaran yang kurang menarik, serta model pembelajaran yang digunakan belum inovatif dan masih belum cukup untuk memfasilitasi pemerolehan pemahaman bagi peserta didik. Kondisi demikian apabila terus dibiarkan akan berdampak buruk terhadap kualitas pembelajaran dan hasil belajar peserta didik.

Menentukan Strategi dan model pembelajaran yang sesuai, sangat diperlukan oleh guru untuk mencapai tujuan yang diinginkan dalam proses pembelajaran. Sehingga dapat memudahkan peserta didik dalam memahami pokok bahasan yang disampaikan oleh guru. Dan guru mendapatkan respon yang di inginkan. Tujuan yang ingin dicapai oleh guru diantarannya adalah menciptakan suasana aktif didalam kelas selama proses belajar mengajar berlangsung. Terciptanya suasana yang aktif di dalam kelas akan berdampak baik bagi Peserta didik, sehingga peserta didik akan mudah menyerap pokok bahasan yang disampaikan oleh guru secara optimal dan maksimal. Didasari beberapa masalah tersebut, maka guru perlu melakukan evaluasi belajar dengan melakukanPenelitian Tindakan Kelas (PTK) bersamaan dengan penerapan kurikulum 2013 dengan pembelajaran tematik terpadu pada tema 4 Berbagai Pekerjaan yang dalam proses pembelajarannya menuntut peserta didik untuk ikut aktif dalam proses belajar mengajar (Bertanya, mengamati, Mengumpulkan informasi, mengasosiasi dan mengkomunikasikan) karena dalam tema ini diharapkan peserta didik dapat menghasilkan proyek atau produk diakhir proses belajar mengajar. Bukan hanya hasil akhir yang akan dinilai akan tetapi dalam kurikulum 2013 diberlakukan penilaian autentik yaitu mulai persiapan, proses sampai hasil yang 
dicapai.

Pembelajaran memperbaiki hasil belajar tersebut, akan digunakan model pembelajaran Problem Based Learning. PBL merupakan pendekatan inovatif yang mengajarkan beragam strategi mencapai kesuksesan abad 21 (Bell, 2010), membantu peserta didik mengembangkan keterampilan abad 21 (Ravitz et.al, 2011), meningkatkan tanggung jawab(Johann et.al, 2006), melatih pemecahan masalah, self direction, komunikasi, dan kreativitas (Wurdinger \& Qureshi, 2015 hlm, 15). Pembelajaran berbasis masalah intinya meletakkan peserta didik sebagai subyek belajar yang aktif, mendorong munculnya inisiatif dan proses eksplorasi, memberikan kesempatan menerapkan apa yang dipelajari, kesempatan untuk mempresentasikan atau mengkomunikasikan dan mengevaluasi kinerjanya pelaksanaannya mengajak peserta didik secara aktif dalam pembelajaran, menemukan, mengumpulkan serta menyajikan informasi baik secara lisan maupun tulis. Sebagaimana disampaikan oleh Ita Purnamasari (2020, hlm 25) model pembelajaran PBL (Problem Based Learning), adalah suatu pendekatan pembelajaran yang menggunakan masalah dunia nyata sebagai suatu konteks bagi peserta didik untuk belajar tentang cara keterampilan pemecahan masalah, serta untuk memperoleh pengetahuan dan konsep esensial dari materi pelajaran. Begitu pula Tan (2003) dalam Rusman (2018, hlm 229) menjelaskan Problem Based Learning merupakan inovasi dalam pembelajaran karena dalam PBL kemampuan berpikir peserta didik betul-betul dioptimalisasikan melalui proses kerja kelompok atau tim yang sistematis, sehingga peserta didik dapat memberdayakan, mengasah, menguji, dan mengembangkan kemampuan berpikirnya secara berkesinambungan.

Model pembelajaran PBL dapat memberikan pengaruh yang positif terhadap hasil belajar peserta didik, karena model pembelajaran PBL memiliki beberapa kelebihan, yaitu: Pertama, peserta didik didorong untuk memiliki kemampuan memecahkan masalah dalam situasi nyata. Kedua, peserta didik memiliki kemampuan membangun pengetahuannya sendiri 
melalui aktivitas belajar. Ketiga,terjadi aktivitas ilmiah pada peserta didik melalui kerja kelompok. Keempat, peserta didik terbiasa menggunakan sumber-sumber pengetahuan, baik dari perpustakaan, internet, wawancara dan observasi. Kelima, peserta didik memiliki kemampuan untuk melakukan komunikasi ilmiah dalam kegiatan diskuisi atau presentasi hasil pekerjaan mereka. Keenam, kesulitan belajar peserta didik secara individual dapat diatasi melalui kerja kelompok dalam bentuk peerteaching (Shoimin 2017, hlm, 132). Sebagaimana disampaikan oleh Rusman (2018, hlm 232) salah satu kelebihan PBL mengoptimalkan tujuan, kebutuhan, motivasi yang mengarahkan suatu proses belajar yang merancang berbagai kognisi pemecah masalah.

Definisi tersebut di atas merujuk pada pendapat beberapa ahli yang memberikan definisi tentang pembelajaran berbasis masalah. Problem Based learning (PBL) adalah suatu model kegiatan di kelas yang berbeda dengan biasanya. Kegiatan pembelajaran berbasis masalah berjangka waktu lama, antardisiplin, berpusat pada siswa dan terintegrasi dengan masalah dunia nyata.

Peneliti ini ingin mengetahui sekaligus membuktikan model Problem Based Learning merupakan salah satu langkah yang di gunakan guru di sekolah tersebut dapat meningkatkan hasil belajar para peserta didiknya, sehingga sekolah tersebut dapat menghasilkan peserta didik yang benar-benar berkualitas serta memahami materi. Tujuan akhir adalah agar peserta didik dapat mengaplikasikan apa yang di pelajarinya, serta dapat menyelesaikan persoalan yang dihadapinya dalam kehidupan sehari-hari.

\section{B. Metode Penelitian}

Metode penelitian yang digunakan oleh peneliti yaitu metode penelitian kualitatif. Menurut Sugiyono (2010, hlm 9). Metode penelitian kualitatif adalah metode penelitian yang berlandaskan filsafat postpositivisme, digunakan untuk meneliti pada kondisi obyek yang ilmiah, (sebagai lawannya adalah eksperimen) dimana peneliti adalah sebagai instrument kunci, pengambilan sampel sumber data dilakukan secara purposive dan snowbaal, teknik pengumpulan 
dengan trianggulasi (gabungan), analisis data bersifat induktif/kualitatif, dan hasil penelitian kualitatif lebih menekankan makna dari pada generalisasi.

Penelitian yang dilakukan dalam bentuk Penelitian Tindakan Kelas (PTK). PTK adalah suatu bentuk penelitian yang dilakukan oleh dosen dalam upayanya untuk memperbaiki dan meningkatkan hasil belajar mahasiswa yang dilakukan dalam proses pembelajaran melalui serangkaian tindakan. Menurut Corey (Abidin, Yunus 2009, hlm 105). "Action Reserch is the process by which practitioners attempt to study their problems scientifically in order to guide, correct, and evaluate their decisions and actions". Bahwa penelitian tindakan kelas merupakan seperangkat kegiatan yang bertujuan untuk memperbaiki dan mengevaluasi keputusan dan tindakan yang dilakukan.

Model PTK yang digunakan dalam penelitian ini yaitu mengacu pada model John Elliot. Model PTK John Elliot menggambarkan pelaksanaan yang terdiri atas dua siklus dengan setiap siklusnya terdiri atas dua atau tiga tindakan, dari setiap tindakan akan menghasilkan tindakan berikutnya manakala dalam tindakan sebelumnya terdapat kelemahan yang harus direfleksi dan dievaluasi, sehingga melalui langkahlangkah tersebut akan lebih memudahkan peneliti dalam upaya meningkatkan hasil belajar mahasiswa.

Adapun populasi yang akan menjadi objek penelitian ini ialah anak siswa-siswi Kelas IV SD Negeri 1 Kebokura Kecamatan Sumpiuh Kabupaten Banyumas. Dengan jumlah siswa 12 siswa, yang terdiri dari 7 siswa putra dan 5 siswa putri.

Adapun pemilihan tempat penelitian dengan pertimbangan:

a) Ditemukannya permasalahan pada hasil belajar anak

b) Letak geografis SDN yang strategis peneliti mengajar dan mengabdi di lembaga tersebut.

\section{C.Hasil Penelitian dan Pembahasan}

\section{Siklus 1}

Alternatif pemecahan masalah untuk mengatasi rendahnya hasil belajar siswa dalam tema 4 dengan menggunakan model pembelajaran Prolemt Based Learning (PBL) di kelas VI SD Negeri 1 Kebokura, ternyata memberikan kenaikan hasil belajar dibandingkan dengan kondisi 
awal.

Pembelajaran menggunakan model pembelajaran Problem Based Learning (PBL), ada kenaikan ketuntasan belajar sebesar $25 \%$. Pada siklus ini terjadi kenaikan ketuntasan belajar yang cukup signifikan dibandingkan dengan kondisi awal. Pemilihan model pembelajaran pembelajaran Problem BasedLearning (PBL) yang tepat oleh guru dalam menumbuhkan minat dan kerjasama siswa merupakan hal yang penting dalam usaha meningkatkan hasil belajar siswa. Dalam menumbuhkan minat dan semangat siswa dalam belajar materi tema 4 (Berbagai pekerjaan), peneliti mengimplementasikan model Problem Based Learning (PBL), yang akhirnya berkolerasi dengan hasil belajar siswa.

\section{Siklus 2}

Berdasarkan hasil refleksi, penggunaan model Project Based Learning dalam pembelajaran, kenaikan siswa terlihat jelas. Ketuntasan mencapai $100 \%$, kenaikan minat belajar mencapai $25 \%$. Sikap kerjasama siswa dalam diskusi kelompok dari siklus I dan siklus II dicatat dalam lembar pengamatan, hasilnya didiskusikan dengan teman sejawat.

Selama pembelajaran siklus I dan II siswa sudah terlihat mau bekerjasama dalam mengikuti pembelajaran. Diskusi kelompok semakin hidup. Siswa berani bertanya tentang materi pelajaran yang belum jelas. Saat presentasi hasil diskusi, siswa berani tampil ke depan. Secara umum kegiatan pembelajaran sudah terlihat baik. Untuk memperoleh hasil yang optimal, pemilihan model pembelajaran perlu memperhatikan jumlah siswa atau besar kecilnya kelas". Ketersediaannya alat peraga juga menjadi faktor penting dalam keberhasilan proses pembelajaran.

Tabel 1.1 Rekapitulasi minat belajar siklus 1 dan siklus 2

\begin{tabular}{|c|c|l|l|l|l|}
\hline No & Tahapan & \multicolumn{2}{|l|}{$\begin{array}{l}\text { Siswa yang } \\
\text { Aktif bertanya }\end{array}$} & \multicolumn{2}{l|}{$\begin{array}{l}\text { Siswa yang } \\
\text { menjawab }\end{array}$} \\
\cline { 3 - 6 } & & Frekuensi & Prosentase & Frekuensi & prosentase \\
\hline 1 & Siklus 1 & 9 & $75 \%$ & 3 & $25 \%$ \\
\hline 2 & Siklus 2 & 12 & $100 \%$ & 0 & $0 \%$ \\
\hline
\end{tabular}

Grafik 1.1 Peningkatan hasil belajar siklus 1 dan 2

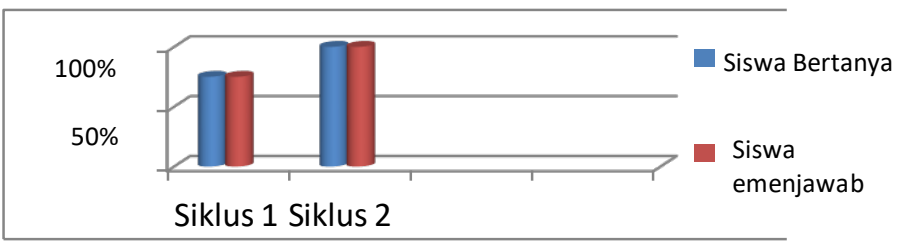


Hasil pembelajaran diperlukan inovasi lain sampai proses pembelajaran berhasil. Faktor lain yang turut memberikan konstribusi terhadap peningkatan hasil belajar siswa adalah diberikannya kesempatan langsung kesempatan siswa untuk menganalisis dan memecahkan langsung terhadap objek yang diajarkan menggunakan media belajar yang objeknya sama dengan objek yang dipelajari. Upaya tersebut dapat memberikan konstribusi yang signifikan.

Hasil dari penelitian ini menunjukan bahwa model Problem Based Learning (PBL) dapat meningkatkan Hasil belajar siswa dalam pembelajaran Tema 4 (BerbagaiPekerjaan) di SD Negeri 1 Kebokura, kecamatan Sumpiuh, Kabupaten Banyumas

\section{Ketuntasan Hasil belajar Siswa}

Melalui hasil penelitian ini menunjukkan bahwa model pembelajaran Problem Based Learning (PBL) memiliki dampak positif dalam meningkatkan hasil belajar siswa. Hal ini dapat dilihatdari semakin mantapnya pemahaman siswa terhadap konsep materi yang disampaikan guru. Rata-rata nilai hasil belajar pada siklus II yaitu 91 . Pada siklus II jumlah siswa yang mencapai ketuntasan belajar sebanyak 12 siswa atau 100\% sehingga telah melampaui indikator keberhasilan yang telah ditetapkan yaitu $70 \%$.

2. Kemampuan Guru dalam Mengelola Pembelajaran

Berdasarkan analisis data, diperoleh sikap kerjasama siswa dalam diskusi kelompok dengan penggunaan model pembelajaran Problem Based Learning (PBL) mengalami peningkatan. Pada akhir siklus II 12 siswa atau 100\% menunjukan sikap kerjasama dalam diskusi kelompok. Hal ini berdampak positif terhadap hasil belajar siswa, terbukti dengan meningkatnya nilai rata-rata siswapada setiap siklus.

3. Aktivitas Guru dan Siswa Dalam Pembelajaran

Berdasarkan analisis data, diperoleh aktivitas siswa dalam proses pembelajaran tema 4 (Berbagai Pekerjaan) dengan model pembelajaran Problem Based Learning ( $P B L$ ) yang paling dominan adalah bekerjasama dalam kelompok dan diskusi antarsiswa/antara siswa dengan guru. Jadi dapat dikatakan 
bahwa aktivitas siswa dapat

dikategorikan aktif.

Aktivitas guru selama pembelajaran, telah melaksanakan langah-langkah pembelajaran model pembelajaran Problem Based Learning (PBL) sesuai RPP. Hal ini terlihat dari aktivitas guru yang muncul di antaranya aktivitas membimbing dan mengamati siswa dalam melaksanakan kegiatan diskusi kelompok dalam mengerjakan LKPD, menemukan konsep, memberi umpan balik/evaluasi/tanya jawab dimanapersentase untuk aktivitas di atas cukup besar.

\section{Kesimpulan}

Dari hasil penelitian tindakan kelas dengan Model Pembelajaran Problem BasedLearning pada Tema 4 (BerbagaiPekerjaan) pada siswa kelas IV SD Negeri 1 Kebokura Kabupaten Banyumas dapat peneliti simpulkan sebagaiberikut:

1. Model Pembelajaran Problem Based Learning (PBL) pada pada tema 4 (Berbagai Pekerjaan dapat meningkatkan hasil belajar siswa kelas IV SD Negeri 1 Kebokura, Kecamatan Sumpiuh, Kabupaten
Banyumas.

2. Model pembelajaran Problem Based Learning (PBL) memiliki dampak positif dalam meningkatkan hasil belajar siswa yang ditandai dengan peningkatan ketuntasan belajar siswa dalam setiap siklus, yaitu siklus I naik $25 \%$ dan siklus II naik 25\%. Model pembelajaran Problem Based Learning (PBL) juga meningkatkan sikap kerjasama siswa yang ditunjukan dalam diskusi kelompok. Pada akhir siklus II, sebanyak 12 siswa atau 100\% menunjukan sikap kerjasama dalam diskusi kelompok.

\section{DAFTAR PUSTAKA}

Susanto, Ahmad. (2013). Teori Belajar dan Pembelajaran di Sekolah Dasar.Jakarta: Kencana.

Suyono dan Hariyanto. (2011). Belajar Dan Pembelajaran. Bandung: PT. Remaja Rosdakarya.

Sabri, Ahmad. 2007. Strategi Belajar Mengajar Dan Micro Teaching. Ciputat: Quantum Teaching.

Rusman. (2018). Model-Model Pembelajaran Pembelajaran Profesionalisme Guru. Depok: PT RajaGrafindo Persada

Shoimin, A. (2017). 68 Model Pembelajaran Inovatif dalam Kurikulum 2013. Yogyakarta: Arruzz Media. 
Permendikbud No. 57 Tahun 2014 tentang Kompetensi Dasar dan Struktur Kurikulum SD/MI.

Rusman. 2011. Model-Model

Pembelajaran. Bandung: Rajawali Pers.

Shoimin, Aris. (2014). 68 Model pembelajaran Inovatif dalam Kurikulum 2013. Yogyakarta: ArRuzzMedia.

Kamdi, W. 2007. Model Model Pembelajaran Inovatif. Malang : Universitas Malang Press.

Trianto, 2009 Mendesain Model Pembelajaran Inovatif-

Progresif. Jakarta Kencana Prenada Group.

Amir, M. T. (2010). Inovasi Pendidikan melalui Problem Based Lerning. Jakarta: Kencana.

Akinoglu, O. dan R.O. Tandogan. 2007. The Effect of Problem Based Active Learning of Student's Academic Achievement, Attitude and Concept Learning. Eurasia Journal of Mathemathics, science \& Technology Education, 3 (1): 71-81. Ibrahim, M. (2000). Pembelajaran kooperatif. Surabaya : UNESA. Universitas Tekan.

Femi Olivia. 2011. Teknik Ujian Efektif. Jakarta: PT Elex Media Komputindo.

Sugihartono, dkk. 2007. Psikologi Pendidikan, Yogyakarta : UNY Press.

Winarni, Endang Widi. (2012). Inovasi Dalam Pembelajaran IPA. Bengkulu:FKIP UNIB

Eni Wulandari, Setyo Budi, Kartika Chrysti Suryandari. (2011) yang bejudul "Penerapan Model PBL (Problem Based Learning) pada Pembelajaran IPA Siswa Kelas V SD FKIP Universitas Sebelas Maret. 